\title{
INTERLEUKIN-8 LEVEL IN THE BLOOD OF RATS WITH EXPERIMENTAL OSTEOARTHRITIS AND HYPOTHYROIDISM
}

\author{
D. S. NOSIVETS \\ SI "Dnipropetrovsk Medical Academy of the Ministry of Health of Ukraine"; \\ e-mail:dsnosivets@ukr.net
}

Received: 9 May 2020; Accepted: 13 November 2020

In the study, the level of interleukin-8 in the blood serum of rats with experimental model of osteoarthritis and hypothyroidism under the influence of NSAID $s$ and paracetamol was estimated. The experiments were performed on 75 white nonlinear rats of both sexes. Experimental osteoarthritis was induced by single intra-articular administration of $0.1 \mathrm{ml}$ of monoiodoacetic acid solution into the knee joint. Experimental hypothyroidism was reconstructed by enteral administration of $0.02 \%$ carbimazole solution, given with a drinking ration for 6 weeks. On the $42^{\text {nd }}$ day of the experiment, the animals were divided into 14 groups and drug administration began daily for 5 days. The serum level of interleukin-8 was estimated on 42 and 47 days of the experiment by specific ELISA kits. A significant decrease $(P \leq 0.05)$ of the elevated cytokine level under the influence of pharmacotherapy was revealed. According to the degree of influence on degenerativedystrophic process in the knee joint, the investigated drugs can be arranged as follows: diclofenac sodium > ibuprofen $>$ nimesulide $=$ meloxicam $>$ celecoxib $>$ paracetamol. The results obtained showed that the level of interleukin-8 could be used as an indicator of non-steroidal drugs and paracetamol anti-inflammatory activity under experimental osteoarthritis and hypothyroidism.

Ke ywords: osteoarthritis, hypothyroidism, NSAIDs, pharmacotherapy, biochemical markers, interleukin-8 (IL 8).

$\mathrm{T}$ o date, there is a clear need for certain factors that could predict the effectiveness of osteoarthritis (OA) treatment, especially in comorbid conditions. It is known that hypofunction of the thyroid gland leads to metabolic disorders that negatively affect the condition of bone and cartilage, causing the development of OA [1, 2].

OA remains the most frequent cause of pain, deformity and dysfunction in the elderly population. One manifestation of OA is considered to be a pathological change from the cartilage and the synovial sheath that responds to the disease by an inflammatory reaction. Although the pathogenesis of OA is far from clear, involvement of inflammation in the development and progression of OA has been implicated. Although NSAIDs (nonsteroidal antiinflammatory drugs) are effective in reducing pain and disability in patients with OA, it is still unclear to what extent these drugs may affect the metabolism of joints and, therefore, the course of OA, especially against the background of functional thyroid insufficiency [3, 4].

The peculiarity of the treatment of OA with concomitant hypothyroidism is in the appointment of basic hormone replacement therapy and NSAIDs, but the question of the effect of NSAIDs on synovial joint and the interaction of these drugs in comorbid pathology in our opinion have not been sufficiently investigated [3-5].

Interleukin-8 (IL 8) is a cytokine present under physiological and pathological conditions that has been shown to play a role in inflammatory. IL 8 produced by OA chondrocytes is an important mediator in the pathophysiology of OA including promotion of a number of pathogenic processes [5-7].

The aim of this work was to study the changes in the level of interleukin- 8 under the influence of non-steroidal anti-inflammatory drugs and 
paracetamol in experimental osteoarthritis and hypothyroidism.

\section{Materials and Methods}

The study was performed on 75 white nonlinear rats weighing 200-250 g, which were kept under standard conditions of the vivarium of the SI "DMA of the Ministry of Health of Ukraine”. Experimental studies have been carried out in accordance with the "General ethical principles of animal experimentation" (Ukraine, 2001), "Bioethical examination of preclinical and other animal research" (Kyiv, 2006) and the provisions of the "European convention for the protection of vertebrate animals used for experimental and other scientific purposes" (Strasbourg, 1986). When conducting the research, the regulation was approved by the ethics committee of the SI "DMA of the Ministry of Health of Ukraine" (protocol number 1 - 18.01.2015).

Experimental osteoarthritis (EOA) was reproduced at the beginning of the study by administering $0.1 \mathrm{ml}$ of monoiodoacetic acid solution (Iodoacetic acid reagent $\geq 98.0 \%$ T, No. I4386, manufactured by Sigma-Aldrich Chemie GmbH, Germany) to the knee joint. The solution of monoiodoacetic acid was prepared at the rate of $3 \mathrm{mg}$ per $50 \mu \mathrm{l}$ of sterile saline $[8,9]$ and from the same day began the formation of experimental hypothyroidism (EH) by enteral administration of $0.02 \%$ solution of carbimazole (drug "Espa-carb”, production of Esparma GmbH, Germany; in tablets $5 \mathrm{mg}$ or $10 \mathrm{mg}$ ), which was prepared at the rate of $5 \mathrm{mg}$ per $250 \mathrm{ml}$ of saline solution and given with the animals' diet for 6 weeks [10].

On 42 day of the experiment animals divided into 14 research groups of 5 rats in each group $(n=5)$ : group I - rats with EOA+ EH without "treatment”; group II - received L-thyroxine (T) (produced by Berlin-Chemie, Germany) in a dose of $1.5 \mu \mathrm{g} / \mathrm{kg}$ (intragastric); group III - diclofenac sodium (D) (produced by PJSC Plant Red star, Ukraine) at a dose of $10 \mathrm{mg} / \mathrm{kg}$ (intragastric); group $\mathrm{IV}-\mathrm{D}+\mathrm{T}$ in the appropriate dosages and routes of administration; group V - ibuprofen (I) (produced by PJSC Borshagovskiy chemical pharmaceutical plant, Ukraine) at a dose of $5 \mathrm{mg} / \mathrm{kg}$ (intragastric); group VI - I+T in the appropriate dosages and routes of administration; VII group - meloxicam (Mel) (produced by PJSC Kiev Vitamin Plant, Ukraine) at a dose of $10 \mathrm{mg} / \mathrm{kg}$ (intragastric); group VIII - Mel+T in the appropriate dosages and routes of administration; group IX - paracetamol (P) (pro- duced by PJSC Pharmaceutical company Darnitsa, Ukraine) at a dose of $150 \mathrm{mg} / \mathrm{kg}$ (intragastric); group $\mathrm{X}-\mathrm{P}+\mathrm{T}$ in the appropriate dosages and routes of administration; group XI - nimesulide (N) (produced by PJSC Lekhim-Kharkov, Ukraine) at a dose of $80 \mathrm{mg} / \mathrm{kg}$ (intragastric); group XII - N+T in the appropriate dosages and routes of administration; group XIII - celecoxib (C) (drug Flogoxib-Health, produced by Health, Ukraine) at a dose of $50 \mathrm{mg} /$ $\mathrm{kg}$ (intragastric); group XIV - C+T in the appropriate dosages and routes of administration. The choice of drugs is based on the requirements of plants for primary health care for the treatment of OA and hypothyroidism (http://guidelines.moz.gov.ua).

The drugs were administered daily from day 42 of the experiment for 5 days in doses and modes listed above. To obtain a homogeneous suspension for intragastric administration tablets used solution of Tween-80 (Polysorbate 80, Ukraine) [11].

The quantitative level of interleukin-8 (IL 8) in serum was performed by specific kits which are based on ELISA (enzyme-linked immunosorbent assay) in vitro twice (on 42 and 47 days of the experiment) using the enzyme immunoassay system "Elabscience" (USA) according to the method of the manufacturer, which was described in the technical documentation. Standard curves for IL 8 were generated by using reference cytokine concentrations supplied by the manufacturer. The sensitivity of this kit is $10 \mathrm{pg} / \mathrm{ml}$. The detection range of this kit is $62.5 \mathrm{pg} / \mathrm{ml}-2000 \mathrm{pg} / \mathrm{ml}$. For the reference level of IL 8 adopted the values obtained in intact rats $(n=5)$ (Table). The blood samples were obtained from the tail vein of the rats by means of puncture using a vacuum system on 42 and 47 days of the experiment [11].

The duration of administration of the drugs was 5 days and by the $47^{\text {th }}$ day of the experiment all animals after the collection of biological material were removed from the study by decapitation under general anesthesia [11, 12].

Statistical differences was performed using the Statistica 6.1 software package (StatSoftInc., Serial number AGAR909E415822FA) and included calculations of arithmetic mean values $(\mathrm{M})$ and their errors $( \pm \mathrm{m})$. The probability of difference of arithmetic mean $(P)$ values was determined using nonparametric - Mann-Whitney U-test. Probabilities of intragroup and between groups differences were determined using Student's parametric $t$-test and ANOVA. The differences were considered statistically significant at $P \leq 0.05$. Before applying the 
parametric criteria, the hypothesis of a normal law of distribution of random variables was tested [13].

\section{Results and Discussion}

The analysis of the results showed that changes in the level of IL 8 in the serum of rats under the influence of NSAIDs and paracetamol occur unequally (Table).

Thus, at day 42 , there was a marked increase in IL 8 in all experimental groups $(P \leq 0.05)$, reflecting the development of pathological changes under the influence of experimental models, which increased by day 47 of the experiment in group I $(P \leq 0.05)$. Under the influence of L-thyroxine replacement therapy, a significant decrease in the level of IL 8 $(P \leq 0.05)$ by $4.87 \%$ was established compared with group I, but a more pronounced decrease in cytokine levels was observed with co-administered L-thyroxine with NSAIDs (Table).

An analysis of the results and their comparison with the level of IL 8 of group I revealed a significant decrease $(P \leq 0.05)$ of the cytokine under the influence of pharmacotherapy. So, in the group III, the cytokine level decreased by $42,81 \%(P \leq 0.05)$, in the group IV by $45.02 \%(P \leq 0.05)$, in group $\mathrm{V}-$ by $31.37 \%(P \leq 0.05)$, in group VI - by $36.52 \%$ $(P \leq 0.05)$, in group VII - by $21.18 \%(P \leq 0.05)$, in group VIII - by $27.52 \%(P \leq 0.05)$, in group IX - by $2.9 \%(P \leq 0.05)$, in group $X$ - by $5.27 \%(P \leq 0.05)$, in group XI - by $21.85 \%(P \leq 0.05)$, in group XII by $28.37 \%(P \leq 0.05)$, in group XIII - by $14.01 \%$ $(P \leq 0.05)$ and group XIV showed a decrease on $16.76 \%(P \leq 0.05)$ (Table).

As can be seen from the table data, when comparing the results with group I (without "'treatment"), a significant $(P \leq 0.05)$ effect of the use of NSAIDs, paracetamol and L-thyroxine on the experimental pathology, which indicates the feasibility of using these drugs, however the degree of their effect on the level of IL 8 serum was different. The smallest effect on IL 8 was observed in the IX and $\mathrm{X}$ groups when using paracetamol and paracetamol with L-thyroxine.

In general, given the results, the degree of impact on the level of IL 8 serum of rats studied drugs can be arranged as follows: diclofenac sodium $>$ ibuprofen $>$ nimesulide $=$ meloxicam $>$ celecoxib $>$ paracetamol, reflecting the different efficacy and pharmacological activity of the indicated on the background of hypothyroidism (Table).

Indicators of serum interleukin-8 (IL 8) in rats against the background of NSAIDs and paracetamol under conditions of osteoarthritis and hypothyroidism $(M \pm m)$

\begin{tabular}{|c|c|c|}
\hline Group, drug and dose & $\begin{array}{c}\text { The level of IL8 at } \\
42 \text { days, } \mathrm{pg} / \mathrm{ml}\end{array}$ & $\begin{array}{c}\text { The level of IL8 at } \\
47 \text { days, } \mathrm{pg} / \mathrm{ml}\end{array}$ \\
\hline Intact rats $(\mathrm{IR})(n=5)$ & $59.20 \pm 3.11^{*}$ & $59.4 \pm 2.70^{*}$ \\
\hline I group EOA+EH without “treatment” $(n=5)$ & $1572.00 \pm 25.88^{\#}$ & $1766.0 \pm 24.08^{\#}$ \\
\hline II group L-thyroxine (T) $1,5 \mathrm{mcg} / \mathrm{kg}(n=5)$ & $1580.00 \pm 29.15^{\#}$ & $1680.0 \pm 28.5^{\#, *}$ \\
\hline III group diclofenac sodium (D) $10 \mathrm{mg} / \mathrm{kg}(n=5)$ & $1570.00 \pm 27.39^{\#}$ & $1010.00 \pm 25.74^{\#, *}$ \\
\hline IV group diclofenac sodium $(\mathrm{D})+\mathrm{L}$-thyroxine $(\mathrm{T})(n=5)$ & $1574.0 \pm 30.5^{\#}$ & $971.00 \pm 29.66^{\#, *}$ \\
\hline V group ibuprofen (I) $5 \mathrm{mg} / \mathrm{kg}(\mathrm{n}=5)$ & $1568.00 \pm 28.64^{\#}$ & $1212.00 \pm 27.75^{\#, *}$ \\
\hline VI group ibuprofen $(\mathrm{I})+$ L-thyroxine $(\mathrm{T})(n=5)$ & $1581.00 \pm 30.08^{\#}$ & $1121.00 \pm 28.81^{\#, *}$ \\
\hline VII group meloxicam (Mel) $10 \mathrm{mg} / \mathrm{kg}(n=5)$ & $1576.00 \pm 20.74^{\#}$ & $1392.00 \pm 23.87^{\#, *}$ \\
\hline VIII group meloxicam $(\mathrm{Mel})+$ L-thyroxine $(\mathrm{T})(n=5)$ & $1577.00 \pm 23.35^{\#}$ & $1280.00 \pm 30.21^{\#, *}$ \\
\hline IX group paracetamol $(\mathrm{P}) 150 \mathrm{mg} / \mathrm{kg}(n=5)$ & $1579.00 \pm 25.84^{\#}$ & $1714.00 \pm 27.02^{\#, *}$ \\
\hline X group paracetamol $(\mathrm{P})+$ L-thyroxine $(\mathrm{T})(n=5)$ & $1578.00 \pm 28.64^{\#}$ & $1673.00 \pm 29.07^{\#, *}$ \\
\hline XI group nimesulide $(\mathrm{N}) 80 \mathrm{mg} / \mathrm{kg}(\mathrm{n}=5)$ & $1573.00 \pm 25.15^{\#}$ & $1380.00 \pm 27.39^{\#, *}$ \\
\hline XII group nimesulide $(\mathrm{N})+$ L-thyroxine $(\mathrm{T})(n=5)$ & $1569.00 \pm 33.80^{\#}$ & $1265.0 \pm 25.0^{\#, *}$ \\
\hline XIII group celecoxib (C) $50 \mathrm{mg} / \mathrm{kg}(n=5)$ & $1582.00 \pm 30.54^{\#}$ & $1517.00 \pm 29.92^{\#, *}$ \\
\hline XIV group celecoxib $(\mathrm{C})+$ L-thyroxine $(\mathrm{T})(n=5)$ & $1571.00 \pm 29.03^{\#}$ & $1470.00 \pm 29.15^{\#, *}$ \\
\hline
\end{tabular}

${ }^{\#}$ Values are significant $(P \leq 0.05)$ with respect to the corresponding Intact rats (IR) indicator; *values are significant $(P \leq 0.05)$ relative to the corresponding group I indicator 
Thus, on the basis of the study, the anti-inflammatory activity of NSAIDs and paracetamol by the level of IL 8 in the blood serum of rats was studied against the background of experimental models of osteoarthritis and hypothyroidism.

Conclusion. Determination of the level of interleukin-8 (IL 8) allows to evaluate the activity of the inflammatory process against the background of experimental equivalents of osteoarthritis and hypothyroidism.

The obtained data on the content of interleukin-8 (IL 8) in the serum of rats reflect the degree of influence of NSAIDs and paracetamol on the activity of the inflammatory process due to the interaction of drugs in experimental osteoarthritis and hypothyroidism.

According to the degree of influence on inflammatory processes in the joint, the investigated drugs can be arranged as follows: diclofenac sodium $>$ ibuprofen $>$ nimesulide $=$ meloxicam $>$ celecoxib $>$ paracetamol.

Conflict of interest. Authors have completed the Unified Conflicts of Interest form at http://ukrbiochemjournal.org/wp-content/uploads/2018/12/ coi_disclosure.pdf and declare no conflict of interest.

Acknowledgements. The author is grateful to the scientific consultants professor Mamchur V.I. and professor Opryshko V.I. for helping with experimental research.

Funding. The study was carried out at the personal expense of the author.

\section{РІВЕНЬ ІНТЕРЛЕЙКІНУ-8 У КРОВІ ЩУ РІВ ЗА ЕКСПЕРИМЕНТАЛЬНОГО ОСТЕОАРТРОЗУ ТА ГІПОТИРЕОЗУ}

\section{Д. С. Носівець}

\section{Д3 «Дніпропетровська медична академія МО3 України»; e-mail: dsnosivets@ukr.net}

Мета роботи дослідити рівень інтерлейкіну-8 під впливом нестероїдних протизапальних засобів та парацетамолу за експериментального остеоартрозу та гіпотиреозу в щурів. Експерименти проведено на 75 білих нелінійних щурах обох статей. Експериментальний остео- артроз було індуковано одноразовим введенням 0,1 мл розчину монойодоцтової кислоти в колінний суглоб, який готували 3 розрахунку 3 мг реагенту на 50 мкл фізіологічного розчину. Експериментальний гіпотиреоз було змодельовано ентеральним введенням $0,02 \%$-го розчину карбімазолу, який готували з розрахунку 5 мг на 250 мл фізіологічного розчину і давали тваринам 3 питним раціоном протягом 6 тижнів. На 42-гу добу експерименту тварин розділили на 14 груп і розпочали щоденне введення ліків протягом 5 діб. Рівень інтерлейкіну-8 в сироватці крові визначався методом IEA in vitro на 42-гу та 47-му добу експерименту. Спостерігали значне зниження $(P \leq 0,05)$ підвищеного рівня цитокінів під впливом лікарських препаратів. За ступенем впливу на дегенеративно-дистрофічний процес у суглобі досліджувані препарати можна розташувати таким чином: диклофенак натрію > ібупрофен $>$ німесулід $=$ мелоксикам $>$ целекоксиб > парацетамол. Встановлено, що визначення рівня інтерлейкіну- 8 дозволяє оцінити протизапальну активність нестероїдних протизапальних засобів та парацетамолу на тлі експериментальних остеоартрозу та гіпотиреозу.

Ключов г слова: остеоартроз, гіпотиреоз, НПЗ3, фармакотерапія, біохімічні маркери, інтерлейкін-8 (ІЛ 8).

\section{References}

1. Nosyvets DS. Influence of functional insufficiency of the thyroid gland on the bone and cartilage tissue. Morphologia. 2019; 13(1): 47-51. (In Russian).

2. Williams GR. Thyroid hormone actions in cartilage and bone. Eur Thyroid J. 2013; 2(1): 3-13.

3. Nosyvets DS. Effect of the combination of nonsteroidal anti-inflammatory drug on the course of osteoarthritis with concomitant hypothyroidism. Probl Endocr Pathol. 2019; (2): 40-45. (In Russian).

4. Nosivets DS. Possibility of sharing L-thyroxine, diclofenac sodium and chondroitin sulfate in hypothyroidism. Bull Probl Biol Med. 2019; 1(2): 172-176. (In Ukrainian).

5. Mobasheri A, Bay-Jensen AC, van Spil WE, Larkin J, Levesque MC. Osteoarthritis Year in Review 2016: biomarkers (biochemical markers). Osteoarthritis Cartilage. 2017; 25(2): 199-208. 
6. Paquet J, Goebel JC, Camille Delaunay C, Astrid Pinzano A, Laurent Grossin L, CournilHenrionnet C, Gillet P, Netter P, Jouzea JY, Moulin D. Cytokines profiling by multiplex analysis in experimental arthritis: which pathophysiological relevance for articular versus systemic mediators? Arthritis Res Ther. 2012; 14(2): R60.

7. Henrotin YE, Labasse AH, Simonis PE, Zheng SX, Deby GP, Famaey JP, Crielaard JM, Reginster JY. Effects of nimesulide and sodium diclofenac on interleukin-6, interleukin-8, proteoglycans and prostaglandin E2 production by human articular chondrocytes in vitro. Clin Exp Rheumatol. 1999; 17(2): 151-160.

8. Nosivets DS. Experimental models of cartilage tissue pathology. Zaporozhye Med J. 2019; 21(4(115)): 554-560. (In Russian).
9. Guingamp C, Gegout-Pottie P, Philippe L, Terlain B, Netter P, Gillet P. Mono-iodoacetateinduced experimental osteoarthritis: a doseresponse study of loss of mobility, morphology, and biochemistry. Arthritis Rheum. 1997; 40(9): 1670-1679.

10. Argumedo GS, Sanz CR, Olguín HJ. Experimental models of developmental hypothyroidism. Horm Metab Res. 2012; 44(2): 79-85.

11. Preclinical research guide for drugs. Ed. AN Mironov. M.: 2012; Part 1. 944 p. (In Russian).

12. Poloz AI, Finogenov AYu. Guidelines for the humane euthanasia of animals. Minsk,2008. 45 p. (In Russian).

13. Kostyuk VO. Applied statistics: Tutorial. Kharkiv: HNUMG im. O.M. Beketova, 2015. 191 p. (In Ukrainian). 